\title{
Spatial analysis of rainfall daily trends and concentration in Chile
}

\author{
Pablo Sarricolea ${ }^{1}$, psarricolea@uchilefau.cl, Javier Martín-Vide²
}

\begin{abstract}
Chile has a great diversity of climates. In average, the rainfall differs between $0.7 \mathrm{~mm}$ (Iquique, North) and $1,814.8 \mathrm{~mm}$ (Valdivia, South) according to the main meteorological stations. The small rainfall amount in the North concentrates on few days, with only 3 days per year. In Central Chile, there are among 16 to 42 rainy days and in the South more than 150 days. In order to understand the correlation between precipitation totals (grouped into 1-mm size classes) and the number of rain days, climatologists use the Concentration Index (CI). In the present study, this index was calculated for 17 meteorological stations across Chile for the period between 1965-2005, also using other indicators: Coefficient of Variation, Temporal irregularity and the relation of precipitation with teleconnections. The results of the CI show a high variation among the regions (from 0.51 to 0.76$)$. The highest one was recorded in La Serena $\left(30^{\circ} \mathrm{S}\right)$, with values higher than 0.70 . From La Serena, the CI decreases gradually, reaching values of about 0.60 in the Atacama Region (North) and further South in the Biobío Region. The concentration of rainfall has increased in the last sub-period (1985-2005), as inter-seasonal variability.
\end{abstract}

Keywords: concentration index, Chile, climatic regionalization, daily precipitation.

\section{Análisis espacial de las precipitaciones diarias y sus tendencias de concentración en Chile}

\begin{abstract}
RESUMEN
Chile posee una gran diversidad de climas. Las precipitaciones son muy dispares, entre $0,7 \mathrm{~mm}$ (Iquique) y $1.814,8 \mathrm{~mm}$ (Valdivia) como media anual entre las estaciones meteorológicas principales. Además se concentran en poquísimos días al año, apenas 3 en el norte, de 16 a 42 días en Chile central y más de 150 días en el sur, lo que refleja su gran variedad pluviométrica. Sin embargo, no se conocen bien las relaciones entre los días de precipitación y sus totales, por lo que se aplica el índice de concentración (Concentration Index, CI) a resolución de un milímetro a 17 observatorios meteorológicos, en el período 1965-2005, los sub-períodos 1965-1984 y 1985-2005, y las distintas estaciones del año. Además se calcularon otros indicadores: el Coeficiente de Variación, el de irregularidad temporal y la relación de la precipitación con teleconexiones. Los resultados indican un elevado rango del CI (de 0,51 a 0,76 ), distinguiendo las áreas al norte del trópico de capricornio y al sur de los $40^{\circ} \mathrm{S}$, donde la concentración es baja o moderada $(<0,60)$. Los valores más altos se alcanzan en La Serena $\left(30^{\circ} \mathrm{S}\right)$, con más de 0,70, disminuyendo gradualmente hacia el norte, con 0,60 en la III región de Atacama, y hacia el sur, con el mismo valor en la VIII región de Biobío. La concentración de las precipitaciones se ha incrementado en el último sub-período (1985-2005), al igual que la variabilidad inter-estacional
\end{abstract}

Palabras clave: Chile, Índice de Concentración, precipitación diaria y regionalización climática.

Recibido el 4 de abril de 2014, aceptado el 1 de junio de 2014.

Department of Geography, University of Chile, Portugal 84, Santiago, Chile.

2 Climatology Group, Department of Physical Geography, University of Barcelona, Spain. 


\section{INTRODUCTION}

The climates of Chile are highly controlled by factors such as geographic latitude, altitude and oceanic influence, among others. They confer a large diversity of climates, in the north there are desert climates and in central Chile predominates the Mediterranean (or subtropical) climate, and in the south a temperate rain, wet maritime and cold steppe climates. Also, the Southeastern Pacific Subtropical Anticyclone (SPSA), with a practically stationary character in the coast of central Chile, the subpolar low pressure belt, and the South American monsoon are the most important regulators of the country's rainfall regimes.

The SPSA, with fluctuations of a few degrees of latitude between winter and summer, causes freezing or gives rise to storms on the subpolar low pressure belt. These storms reach lower latitudes during winter, and diminish in summer. This largely explains the rainfall in Chile, moreover if we add the importance of teleconnections -such as the Pacific Decadal Oscillation (PDO), El Nino Southern Oscillation (ENSO, studied, among others, by the Southern Oscillation Index), and the Antarctic Oscillation (AAO)-, which together explain the seasonal and annual variability of rainfall throughout Chile.

The efforts of analytical climatology have been oriented almost exclusively to establish monthly and annual averages, leaving out daily information (even hourly). In this regard, daily climate information has a large potential for characterizing rainfall. At the same time, working at a daily resolution is a challenge in terms of access and data processing, since it involves handling large databases (over 10.950 daily records in a series of 30 years).

It is known that an amount or monthly average of rain provides valuable information on rainfall over a territory, but it tells us nothing about the frequency, neither the number of rainy days, or the breakdown of the recorded amounts of rainy days. The temporal variability of rainfall has been usually calculated and summarized on a monthly, seasonal and annual basis in climate series by statisticians, using among others the range, variance, coefficient of variation $(\mathrm{CV})$, the standard deviation and, more recently, the temporal irregularity index $\left(\mathrm{S}_{1}\right.$, proposed by MARTIN-VIDE et al. 2001). The temporal irregularity index, considers the order of the values in the series. Note that all these statistical parameter that express the rainfall variability are usually applied on monthly or annual amounts, rarely on a daily basis.

Given this situation, solutions of a bidimentional character are required, such as the problem of knowing how precipitations are temporarily distributed in detail (high resolution). These solutions not only consider the total rainfall, but also the number of recorded days. In this regard, a similar solution to the Gini Coefficient was reached. Gini is a measure of the inequality of a distribution, a value of 0 is expressing total equality and a value of 1 maximal inequality. In order to graph the Gini coefficient, maps were used (ranging from 0 to 1), as well as the Lorenz Curve. On the cartesian graph, a straight diagonal line represents perfect equality of wealth distribution; the Lorenz curve lies beneath showing the reality of wealth distribution. The difference between the straight line and the curved line is the amount of inequality of wealth distribution, a figure described by the Gini Coefficient.

Based on the Gini Coefficient, MARTÍNVIDE (1984) formulated the concentration index (CI), specifically for the study of daily rainfall in the Spanish Mediterranean coast. The CI is a synthetic indicator which calculates the degree of rainfall concentration. Additionally, the CI is an estimate of the degree of aggressiveness or extremely torrential rainfall. The concentration index have been extended 
to the entire Iberian Peninsula (MARTÍNVIDE 2004; SÁNCHEZ-LORENZO \& MARTÍN-VIDE 2006), with results that reveal high daily concentration of rainfall in the eastern frontage of the Iberian Peninsula, but having moderate concentrations $(<0,58)$ in the rest of the territory. Furthermore, the rainfall was grouped into classes of $1 \mathrm{~mm}$, and recently in classes of 5 and $10 \mathrm{~mm}$ (BENHAMROUCHE \& MARTÍN-VIDE 2012), with similar results.

Beginning with the results obtained for the Iberian Peninsula, the following hypothesis has been formulated: In regions with a climate of Mediterranean character, concentrations must attain high values, while towards the south of Chile, which has a wetter, oceanic climate, the value of the CI should be rather modest. Both, Chile and the Iberian Peninsula are located in western facades of continents on which they are placed, and are subject to situations of similar atmospheric circulation, except for the tropical desert region.

However, considering only the Iberian Peninsula, it is not possible to propose a hypothesis on the possible values of $\mathrm{CI}$ in northern Chile, since its climate is arid and semiarid, with extremely low number of rainy days. Nonetheless, the study of daily pluviometric information using CI has also been performed in other regions of the planet. In Iran (ALIJANI et al. 2008), where the climate has very low rainfall, CI values were found higher that those recorded in Mediterranean climates of Spain, hence it could be expected in northern Chile that the concentration of precipitation increases.

It has been found that the CI has been recently applied in coastal regions in southern China (ZHANG et. al 2009), near the Tropic of Cancer (between $22^{\circ}$ and $26^{\circ} \mathrm{N}$ ). Results are striking, since the concentration index reaches values higher than 0.78. Also in China, the Xinjiang region has been regionalized using the CI (LI et al. 2011). Xinjiang has, among its singularities, a continental climate, as well as the world's largest differences between its lowest and highest altitude (from -156 to $8.058 \mathrm{~m}$ ) with values between 0.58 and 0.70 respectively. The values of CI correspond to weather stations with less than $81 \mathrm{~mm}$ annual rainfall, and altitudes between 800 $\mathrm{m}$ and $1.500 \mathrm{~m}$.

The researches carried out so far to explain and understand rainfall in Chile have attributed great importance to orographic teleconections. QUINTANA \& ACEITUNO (2006) indicate that there is a clear interdecadal variability in the rainfall regime of central Chile, which seems to be related to changes in the intensity of SPSA, affected by the Pacific Decadal Oscillation (PDO) and ENSO (as measured by the SOI). Hence, the decreasing rainfall coincides with significant intensification of SPSA, positive SOI, and a cool phase of the PDO. While a weakening of the anticyclone leads to increased rainfall, as well as a negative phase of the SOI (El Niño) and a warm phase of the PDO. The hypothesis formulated is, a relationship between the SOI, its decadal pattern (PDO) and the concentration index, in which a negative phase of the SOI (El Niño), and a warm phase of the PDO rains more, but less concentrated. While in a positive phase of the SOI (La Nina) and a cold phase of the PDO it rains less but is more concentrated in few days. Finally, as a complement, the relationship between the rainfall and the different phases of the Antarctic Oscillation (AAO, by THOMPSON \& WALLACE 2000), should be looked for. This should indicate that during the negative phase of the AAO index, more rainfall, by enhanced frontal activity, will take place south of $40^{\circ} \mathrm{S}$. That is, there is a negative relationship between the AAO index and the rainfall in southern Chile. During the positive phases of the AAO, there is a reduction of the west zonal circulation, and therefore, less frontal and orographic rainfall in the area (GARREAUD 2007), which moves further south than normal (SILVESTRI \& VERA 
2003). Therefore, in the positive phase of the AAO, a positive relationship between the Antarctic Oscillation and the rainfall is expected for Punta Arenas. Finally, the purpose of this paper is to characterize the precipitation through irregularity indexes and teleconnections, regionalizing Chile.

\section{MATERIALS AND METHODS}

To analyze rainfall the information about the amounts of precipitations of a total of 17 weather stations were used, which are distributed throughout continental Chile, over a period of 41 years (1965 - 2005). Daily rainfall data was obtained. All data corresponds to official stations of the Meteorological Direction of Chile.

First, the mean, standard deviation, coefficient of variation (CV), the temporal irregularity index $\left(\mathrm{S}_{1}\right)$ and the number (and percentage) of rainy days in a year were calculated for each station. For $\mathrm{S}_{1}$, the sequence of the serial data proposed by MARTIIN-VIDE (2003) is considered. The $\mathrm{S}_{1}$ is constructed according to the expression:

$\mathrm{S}_{1}=(1 /(\mathrm{n}-1)) \sum\left|\ln \left(\mathrm{P}_{\mathrm{i}+1} / \mathrm{P}_{\mathrm{i}}\right)\right|$

Where, $\mathrm{P}_{\mathrm{i}}=$ precipitation for year $i$.

It should be mentioned that a high $\mathrm{S}_{1}$ is characteristic of the Mediterranean climate of the Iberian Peninsula.

The concentration index of a station has been obtained by the analysis of its data on a daily basis. From the database, classes of $1 \mathrm{~mm}$ rainfall have been grouped, then to proceed to count the number of rainy days in each class. The CI has a value between 0 and 1 , and relates to the area between the exponentially fitted curve and the diagonal of the square of either 100 or 10,000 area units. Specifically, the CI is calculated as the proportion of the chosen area under the diagonal $\left(S^{\prime} / 5,000\right)$, and to obtain it, the area below the exponential curve must be known (A'). This exponential fit relates the percentage of rainy days to the total, both accumulated. Figure 1 shows the geometric and mathematical CI expression, omitting the calculation the constants a and $b$, that can be determined by means of the leastsquares method, which can be reviewed in MARTÍN-VIDE (2004).

In the graph of the CI, curve figures have been made in Microsoft Excel, as well as maps containing the spatial distribution of $\mathrm{CI}, \mathrm{CV}$, and $\mathrm{S}_{1}$, using software Arc-Gis 10.1. Also, each station annual precipitation was correlated with SOI (available http:// www.cru.uea.ac.uk/cru/data/soi/soi.dat), PDO (available http://jisao.washington.edu/ pdo/PDO.latest) and AAO index (available www.jisao.washington.edu/aao/slp/), which allows to establish a climatic regionalization of its scope and effects.

\section{RESULTS}

\section{Analysis of rainfall in selected meteorological stations}

As it is known, there is a noticeable increase in the rainfall amounts from Arica to Puerto Montt, although both stations are not rainfall extremes (Table 1). Circulation patterns (westerly winds, sub-low) and topography cause less rain in Punta Arenas (only 390.1 $\mathrm{mm})$. Also, may be notice that Santiago, Osorno and Balmaceda stations located inland, have lower values compared to the same latitude stations, but located closer to the coast, such as Valparaíso, Valdivia and Coyhaique.

With regard to the variational coefficients, values are higher north of Chillán, especially Iquique with a $301 \%$, although decisively influenced by only $0.7 \mathrm{~mm}$ as the mean annual rainfall. In the south, variational coefficients are modest, especially Temuco, Valdivia and Osorno, with $18 \%$, and Puerto Montt, with $16 \%$. In reviewing the temporal 
irregularity index $\left(\mathrm{S}_{1}\right.$, in Table 1$)$, its values correlate fairly well with the variational coefficient, with the exception of the five northern weather stations. These have very high values of $\mathrm{CV}$, due to the low mean and varied values of $S_{1}$. Iquique is the most notable case, with a $S_{1}$ of 1.7 , with a number of years with zero totals (mathematical indeterminacy is solved by adding a few tenths of $\mathrm{mm}$ to zero totals).

The spatial pattern described above is reinforced by the number and percentage of days of rain in a year (considering days of at least $0.1 \mathrm{~mm}$ of rain). There is an increase of rainy days from Arica and Iquique to Puerto Montt, from less than 2 days to about 220 days per year. This declines slightly towards Punta Arenas, with 150 days per year. Regarding the seasonality of rainfall, there are four clear regimes of rainfall: winter, autumn, spring, and summer. Therefore, winter is the wettest and summer is the driest in virtually all Chilean territory. Arica and Iquique differ from this regime due to the summer rainfall triggered by the South American monsoon system, as well as Antofagasta, where the spring is the second season with the highest rainfall, and Punta Arenas where the maximum rainfall is in autumn.

Regarding the relationship between rainfall, ENSO, and AAO, both teleconnections affect central Chile from La Serena to Valdivia, with a significant and negative correlation. Further south, the importance lies exclusively in the AAO, with high negative correlations for the precipitations of Puerto Montt, Coyhaique and Balmaceda; and a positive correlation, although not significant, between AAO and the precipitations of Punta Arenas (see Table 2); this is due to the fact that during positive phases of the AAO cyclone activity develops further south than is normal.

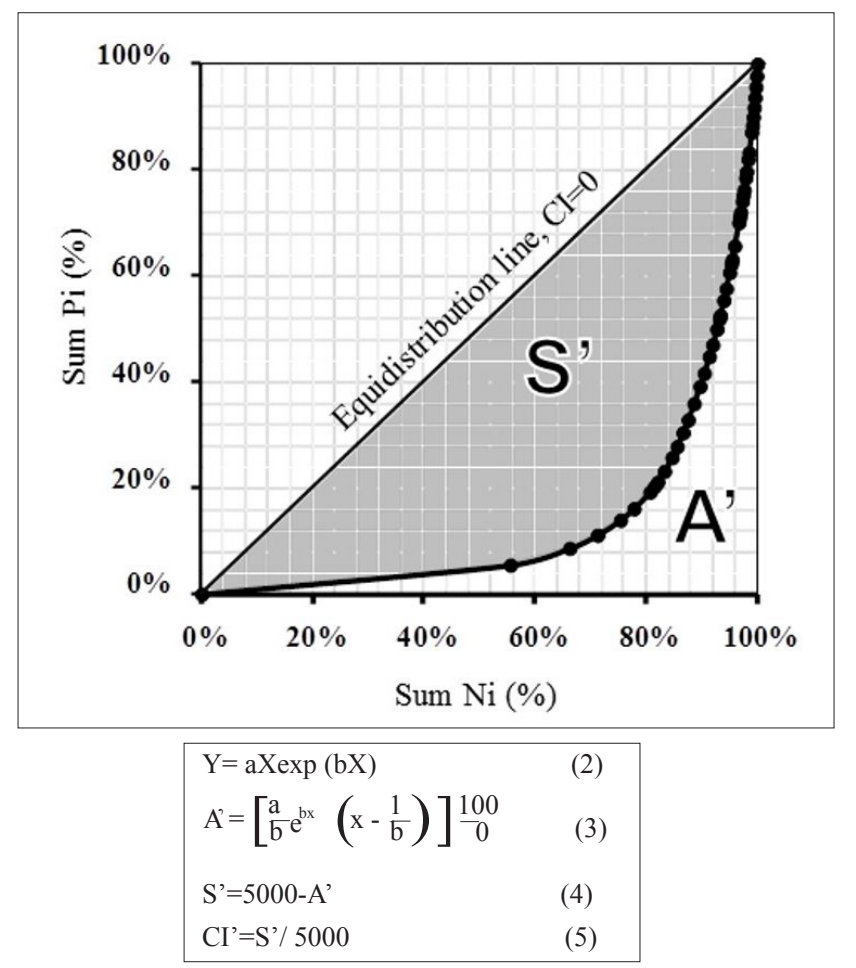

Fig. 1. Exponential curve of accumulated number of precipitation days (Sum Ni) versus amount of accumulated precipitation (Sum Pi). The solid black line represents the equidistribution line (i.e. the case in which the total precipitation is accumulated in days with equal daily precipitation accumulations). 


\section{Concentration index of rainfall}

The daily precipitation concentration studied by CI reflects that the stations of Arica, Antofagasta, Iquique and Puerto Montt present values less and equal to 0.57 (Fig. 2). There is an interesting similarity of values between Iquique and Antofagasta, on one hand, and Puerto Montt, on the other, with largely different total annual amounts of rainy days.

CI reaches its highest values in La Serena (0.76), followed by Copiapó (0.68),
Valparaíso (0.64), and Santiago (0.63). In summary, it is possible to say that maximum values of CI are obtained in central Chile, precisely in the presence on Mediterranean climate with varying degrees of aridity, and where much of the rains of some magnitude are concentrated in a few days. From central Chile, the CI decreases towards the northern desert and also towards the southern rain temperate areas. In the case of rainy meteorological stations (temperate and maritime) rainfall is well distributed throughout the year.

Table 1. Geographical coordinates, annual mean precipitation (P), STANdard deviation (STD) AND MEAN NUMBER OF RAINY DAYS (N) (DAILY PRECIPITATION $\geq 0.1$ MM) FOR 17 METEOROLOGICAL STATIONS ACROSS ChILE.

\begin{tabular}{|c|c|c|c|c|c|c|c|c|c|}
\hline $\begin{array}{l}\text { Meteorologi- } \\
\text { cal stations }\end{array}$ & $\begin{array}{l}\text { Latitude } \\
\left.\text { ( }{ }^{\circ} \mathrm{S}\right)\end{array}$ & $\begin{array}{l}\text { Longitude } \\
\qquad\left({ }^{\circ} \mathrm{W}\right)\end{array}$ & $\begin{array}{c}\text { Elevation } \\
\text { (m) }\end{array}$ & $P(\mathrm{~mm})$ & STD & CV & $S 1 \times 100$ & $\mathrm{~N}$ & Regime* \\
\hline Arica & $18^{\circ} 20^{\prime}$ & $70^{\circ} 20^{\prime}$ & 58 & 1.5 & 2.1 & $139 \%$ & 66.3 & 1.9 & W-Sm-A-S \\
\hline Iquique & $20^{\circ} 32^{\prime}$ & $70^{\circ} 11^{\prime}$ & 52 & 0.7 & 2.2 & $301 \%$ & 1.7 & 0.5 & W-A-Sm-S \\
\hline Antofagasta & $23^{\circ} 26^{\prime}$ & $70^{\circ} 26^{\prime}$ & 135 & 4.6 & 5.2 & $111 \%$ & 72.0 & 2.4 & W-S-A-Sm \\
\hline Copiapó & $27^{\circ} 18^{\prime}$ & $70^{\circ} 25^{\prime}$ & 291 & 16.4 & 24.1 & $147 \%$ & 94.9 & 2.9 & W-A-S-Sm \\
\hline La Serena & $29^{\circ} 54^{\prime}$ & $71^{\circ} 21^{\prime}$ & 142 & 78.7 & 57.2 & $73 \%$ & 102.7 & 16.0 & W-A-S-Sm \\
\hline Valparaíso & $33,{ }^{\circ} 01 '$ & 71039' & 41 & 411.8 & 191.7 & $47 \%$ & 65.3 & 33.5 & W-A-S-Sm \\
\hline Santiago & $33^{\circ} 26^{\prime}$ & $70^{\circ} 41^{\prime}$ & 520 & 330.0 & 159.2 & $48 \%$ & 69.6 & 39.4 & W-A-S-Sm \\
\hline Curicó & $34^{\circ} 58^{\prime}$ & $71^{\circ} 14^{\prime}$ & 225 & 722.9 & 270.0 & $37 \%$ & 53.0 & 54.2 & W-A-S-Sm \\
\hline Chillán & $36^{\circ} 34^{\prime}$ & $72^{\circ} 02^{\prime}$ & 124 & 1083.4 & 288.2 & $27 \%$ & 41.7 & 86.6 & W-A-S-Sm \\
\hline Concepción & $36^{\circ} 46^{\prime}$ & $73^{\circ} 03$ & 12 & 1127.4 & 256.0 & $23 \%$ & 36.4 & 102.6 & W-A-S-Sm \\
\hline Temuco & $38^{\circ} 45^{\prime}$ & $72^{\circ} 38^{\prime}$ & 114 & 1175.4 & 216.5 & $18 \%$ & 28.6 & 148.7 & W-A-S-Sm \\
\hline Valdivia & $39^{\circ} 37^{\prime}$ & $73^{\circ} 05^{\prime}$ & 19 & 1814.8 & 324.0 & $18 \%$ & 28.1 & 174.1 & W-A-S-Sm \\
\hline Osorno & $40^{\circ} 36^{\prime}$ & $73^{\circ} 03^{\prime}$ & 65 & 1330.3 & 236.5 & $18 \%$ & 25.7 & 171.5 & W-A-S-Sm \\
\hline Puerto Montt & $41^{\circ} 25^{\prime}$ & $73^{\circ} 03^{\prime}$ & 85 & 1724.3 & 276.3 & $16 \%$ & 22.6 & 219.8 & W-A-S-Sm \\
\hline Coyhaique & $45^{\circ} 35^{\prime}$ & $72^{\circ} 07^{\prime}$ & 310 & 1103.3 & 322.6 & $29 \%$ & 22.0 & 171.5 & W-A-S-Sm \\
\hline Balmaceda & $45^{\circ} 55^{\prime}$ & $71^{\circ} 41^{\prime}$ & 520 & 595.6 & 144.0 & $24 \%$ & 26.3 & 124.1 & W-A-S-Sm \\
\hline Punta Arenas & $53^{\circ} 00^{\prime}$ & $70^{\circ} 58^{\prime}$ & 37 & 390.5 & 83.4 & $21 \%$ & 30.6 & 150.2 & A-Sm-W-S \\
\hline
\end{tabular}

* W=Winter, $\mathrm{S}=$ Spring, $\mathrm{Sm}=$ Summer and $\mathrm{A}=$ Autumn. 
Table 2. Pearson correlations between annual rainfall of the Meteorological stations analyzed and Southern Oscillation Index (SOI) ANd Antarctic Oscillation Index (AAO).

\begin{tabular}{|c|c|c|c|c|c|}
\hline $\begin{array}{c}\text { Meteorological } \\
\text { stations }\end{array}$ & $\begin{array}{c}\text { Latitude } \\
\left({ }^{\circ} \mathrm{S}\right)\end{array}$ & $\begin{array}{c}\text { Longitude } \\
\left({ }^{\circ} \mathrm{W}\right)\end{array}$ & $\begin{array}{c}\text { Elevation } \\
(\mathrm{m})\end{array}$ & $\begin{array}{c}\text { Pearson correlations between } \\
\text { annual rainfall and Southern } \\
\text { Oscillation Index (SOI) }\end{array}$ & $\begin{array}{c}\text { Pearson correlations between } \\
\text { annual rainfall and Antarctic } \\
\text { Oscillation Index (AAO) }\end{array}$ \\
\hline Arica & $18^{\circ} 20^{\prime}$ & $70^{\circ} 20^{\prime}$ & 58 & -0.22 & -0.06 \\
\hline Iquique & $20^{\circ} 32^{\prime}$ & $70^{\circ} 11^{\prime}$ & 52 & -0.28 & -0.08 \\
\hline Antofagasta & $23^{\circ} 26^{\prime}$ & $70^{\circ} 26^{\prime}$ & 135 & -0.06 & -0.20 \\
\hline Copiapó & $27^{\circ} 18^{\prime}$ & $70^{\circ} 25^{\prime}$ & 291 & $-0.38^{*}$ & -0.11 \\
\hline La Serena & $29^{\circ} 54^{\prime}$ & $71^{\circ} 21^{\prime}$ & 142 & $-0.37^{*}$ & $-0.39^{*}$ \\
\hline Valparaíso & $33^{\circ} 01^{\prime}$ & $71^{\circ} 39^{\prime}$ & 41 & $-0.49^{*}$ & $-0.38^{*}$ \\
\hline Santiago & $33^{\circ} 26^{\prime}$ & $70^{\circ} 41^{\prime}$ & 520 & $-0.52^{*}$ & -0.16 \\
\hline Curicó & $34^{\circ} 58^{\prime}$ & $71^{\circ} 14^{\prime}$ & 225 & $-0.41^{*}$ & -0.29 \\
\hline Chillán & $36^{\circ} 34^{\prime}$ & $72^{\circ} 02^{\prime}$ & 124 & $-0.50^{*}$ & $-0.38^{*}$ \\
\hline Concepción & $36^{\circ} 46^{\prime}$ & $73^{\circ} 03$ & 12 & $-0.40^{*}$ & $-0.38^{*}$ \\
\hline Temuco & $38^{\circ} 45^{\prime}$ & $72^{\circ} 38^{\prime}$ & 114 & $-0.45^{*}$ & $-0.37^{*}$ \\
\hline Valdivia & $39^{\circ} 37^{\prime}$ & $73^{\circ} 05^{\prime}$ & 19 & $-0.40^{*}$ & $-0.44^{*}$ \\
\hline Osorno & $40^{\circ} 36^{\prime}$ & $73^{\circ} 03^{\prime}$ & 65 & -0.21 & $-0.34^{*}$ \\
\hline Puerto Montt & $41^{\circ} 25^{\prime}$ & $73^{\circ} 03^{\prime}$ & 85 & -0.28 & $-0.61^{*}$ \\
\hline Coyhaique & $45^{\circ} 35^{\prime}$ & $72^{\circ} 07^{\prime}$ & 310 & -0.10 & $-0.57^{*}$ \\
\hline Balmaceda & $45^{\circ} 55^{\prime}$ & $71^{\circ} 41^{\prime}$ & 520 & -0.21 & $-0.48^{*}$ \\
\hline Punta Arenas & $53^{\circ} 00^{\prime}$ & $70^{\circ} 58^{\prime}$ & 37 & -0.16 & 0.27 \\
\hline
\end{tabular}

* Significant correlation ( $\mathrm{p}$ value $<0.05$ ).

Interestingly, more climates that are arid (Arica, Iquique and Antofagasta) have a low value of $\mathrm{CI}$, even though it rains fewer and concentrate lier. The $\mathrm{CI}$ was designed to discriminate between regions where rainfall is well distributed versus regions with high rain concentration. However, it seems that the $\mathrm{CI}$ is not the best indicator of climatic regionalization below certain extreme thresholds. For instance, regions where the first class is very common and agglutinates more than $20 \%$ of the total rainfall amount, such as the case of Arica, Iquique and Antofagasta, shown in Table 3, Table 4, and Table 5.

Regarding the spatial representation, figure 3 shows La Serena with a maximum CI value, establishing a core from which the isopleths are zonally arranged until near to Curicó. From Curicó to Puerto Montt, the isopleths are arranged in a Meridianal way, with lower values of CI. From Puerto Montt (having the lowest concentration of southern Chile, with an CI of 0.56) to further south isopleths retrieve their zonal orientation.

There is a high positive correlation between the values of CI and CV from La Serena and further south $\left(\mathrm{R}^{2}\right.$ of 0.88 , p-value of 0.0000 ), as well as between the values of CI and $\mathrm{S} 1\left(\mathrm{R}^{2}\right.$ of 0.802 and $\mathrm{p}$-value of 0.0001$)$. That is at lower interannual variability and irregularity, lower daily rainfall concentration. 
The concentration index has been calculated for three periods and the four seasons of the year. Results indicate an increase of the CI in the last 20 years (1985-2005) in most of the analyzed stations (Table 6). The only exceptions to this trend are Arica (autumn and spring), Iquique (summer, autumn and spring), Antofagasta (summer, autumn and spring), Copiapó (spring), Coyhaique and Balmaceda (autumn).
It is also possible to notice that the stations with more variability between seasons are Iquique (21\% y $17 \%)$, Copiapó $(20 \%)$ and La Serena (12\%). Further south, interseasonal variability is unimportant. But it should be noted for the period of 1985-2005 has increased with respect to the period of 1965-1984. This suggests an increase of the inter-seasonal variability throughout the full period of analysis.

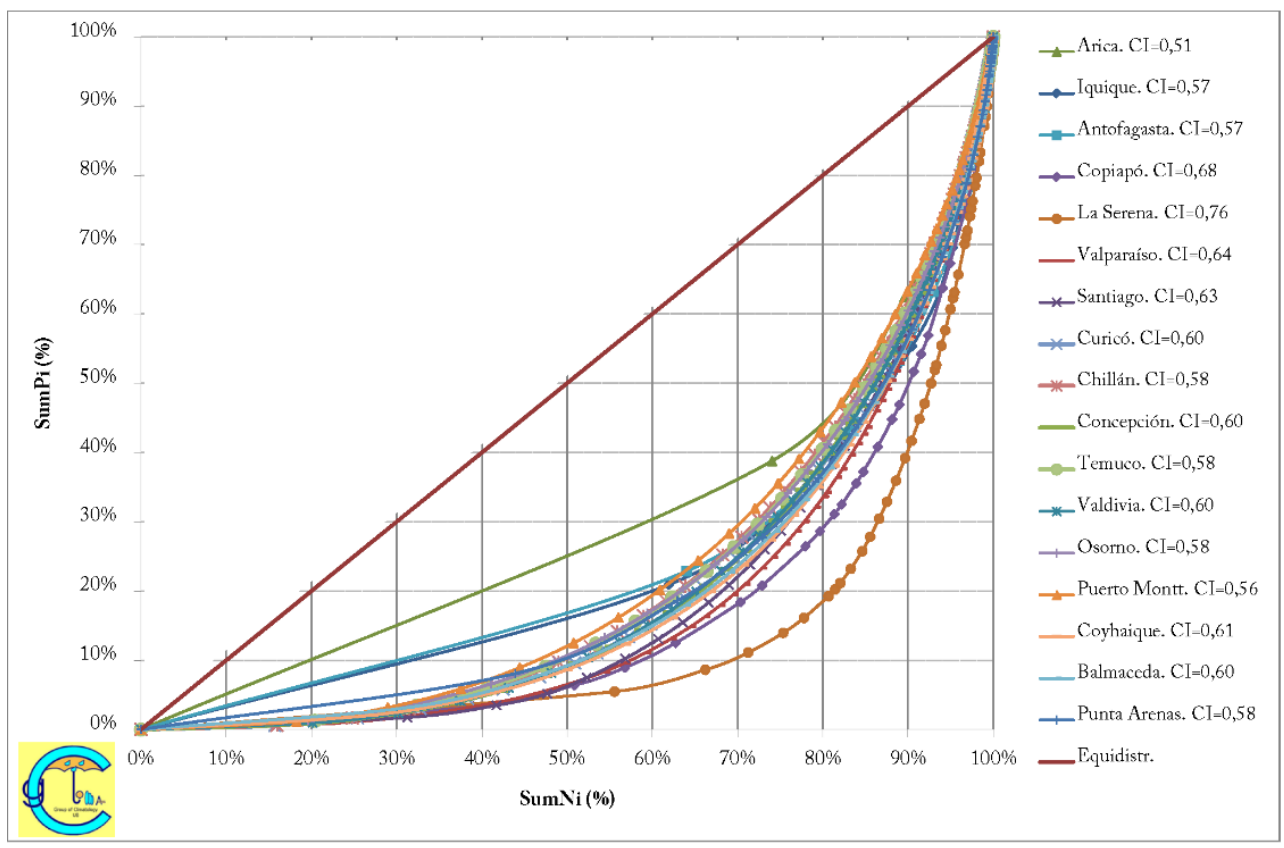

Fig. 2. Concentration curves of the 17 Meteorological stations analyzed for Chile,

Period 1965-2005.

The evident increase of rainfall concentration in the last sub-period (19852005) has been accompanied by a positive PDO index ( 0.38 average) compared to the first sub-period (1965-1984) in which the PDO showed a cold phase (1965-1975) and an average of -0.1 . Something very similar happened with the ENSO phenomenon, which has increased the El Niño phase (negative SOI) from 1977 onwards. Regarding the Antarctic Oscillation Index, the sub-period shows higher occurrence of negative phases (-0.65 on average) between 1965 and 1984, implying that in the second sub-period the polar front was located further north. In consequence, the highest concentration of rainfall for the period of 1985-2005 can be attributed to the further development of El Niño (favored by the warm phase of PDO) and the south displacement of the polar front, seen in the positive values of the Antarctic Oscillation index.

The daily rainfall concentration obtained by the CI confirms that central and southern Chile has a similar configuration to that of the Iberian Peninsula. That is a high value of CI for Mediterranean climates and moderate or low values for rainy ocean climates. 


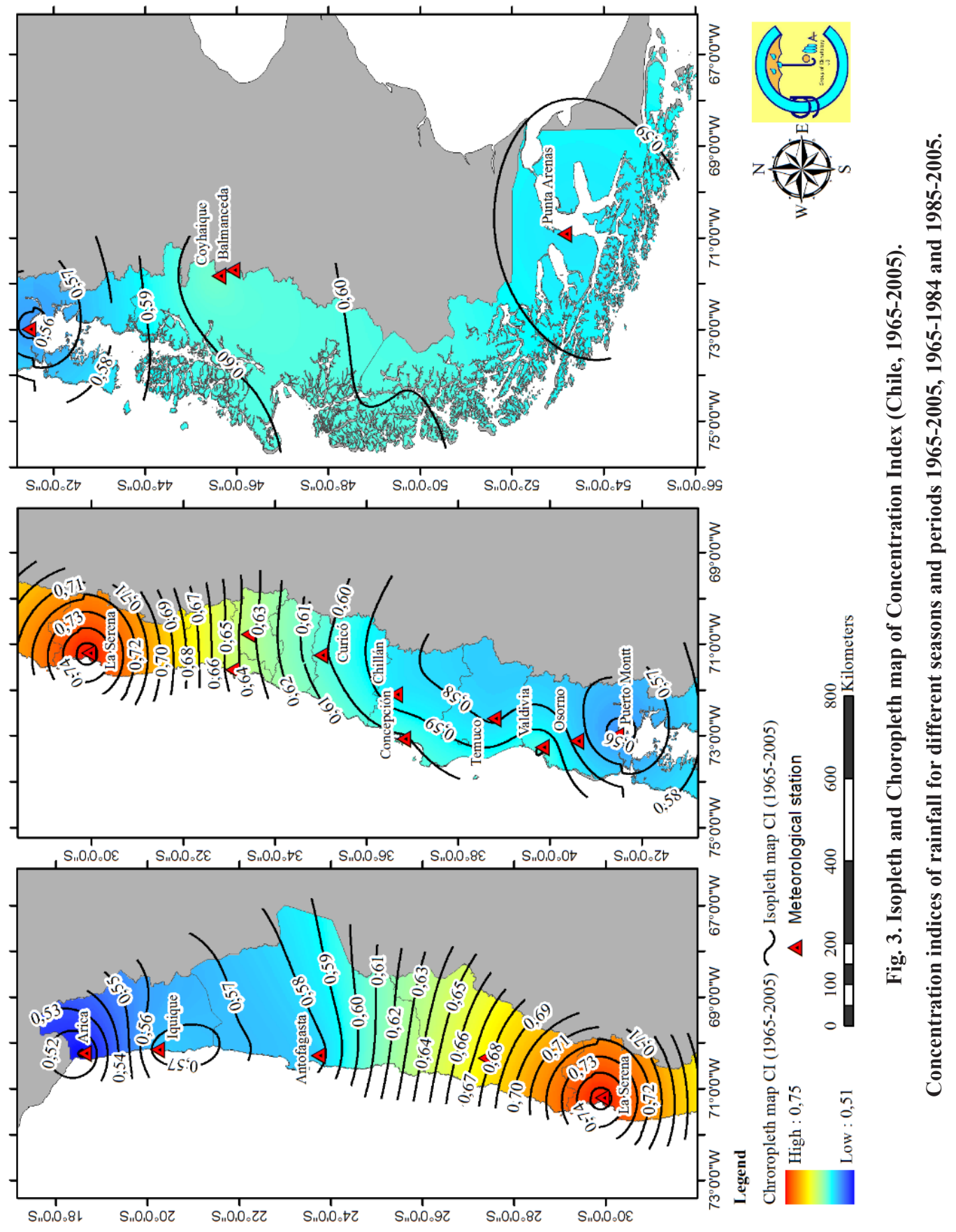


Table 3. Frequency distribution in 1 mm Classes, Relative CUMUlative frequencies $\mathbf{X}$ and the CORRESPONDING PERCENTAges of the total PRECiPitation Y in ARica (1965-2005).

\begin{tabular}{|c|c|c|c|c|c|c|c|}
\hline Class & Midpoint & $\mathrm{n}_{\mathrm{i}}$ & $\sum \mathrm{n}_{\mathrm{i}}$ & $\mathrm{p}_{\mathrm{i}}$ & $\sum \mathrm{p}_{\mathrm{i}}$ & $\sum \mathrm{n}_{\mathrm{i}}(\%)=\mathrm{X}$ & $\sum \mathrm{p}_{\mathrm{i}}(\%)=\mathrm{Y}$ \\
\hline $0.1-0.9$ & 0.5 & 57 & 57 & 28.5 & 28.5 & $74 \%$ & $39 \%$ \\
\hline $1-1.9$ & 1.45 & 12 & 69 & 17.4 & 45.9 & $90 \%$ & $62 \%$ \\
\hline $2-2.9$ & 2.45 & 6 & 75 & 14.7 & 60.6 & $97 \%$ & $82 \%$ \\
\hline $4-4.9$ & 4.45 & 1 & 76 & 4.45 & 65.05 & $99 \%$ & $89 \%$ \\
\hline $8-8.9$ & 8.45 & 1 & 77 & 8.45 & 73.5 & $100 \%$ & $100 \%$ \\
\hline
\end{tabular}

Table 4. Frequency distribution in 1 mm Classes, Relative CUMUlative frequencies $\mathbf{X}$ and the CORRESPONDING PERCENTAGES OF THE TOTAL PRECIPITATION Y IN IQUIQUE (1965-2005).

\begin{tabular}{|c|c|c|c|c|c|c|c|}
\hline Class & Midpoint & $\mathrm{ni}$ & $\sum \mathrm{ni}$ & $\mathrm{pi}$ & $\sum \mathrm{pi}$ & $\sum \mathrm{ni}(\%)=\mathrm{X}$ & $\sum \mathrm{pi}(\%)=\mathrm{Y}$ \\
\hline $0.1-0.9$ & 0.5 & 13 & 13 & 6.5 & 6.5 & $62 \%$ & $21 \%$ \\
\hline $1-1.9$ & 1.45 & 4 & 17 & 5.8 & 12.3 & $81 \%$ & $40 \%$ \\
\hline $2-2.9$ & 2.45 & 2 & 19 & 4.9 & 17.2 & $90 \%$ & $55 \%$ \\
\hline $4-4.9$ & 4.45 & 1 & 20 & 4.45 & 21.65 & $95 \%$ & $70 \%$ \\
\hline $9-9.9$ & 9.45 & 1 & 21 & 9.45 & 31.1 & $100 \%$ & $100 \%$ \\
\hline
\end{tabular}

Table 5. Frequency distribution in 1 mm Classes, Relative CUMUlative Frequencies $X$ and the CORRESPONDING PERCENTAGES OF the tOtAl PRECiPitation Y in ANTOFAgasta (1965-2005).

\begin{tabular}{|c|c|c|c|c|c|c|c|}
\hline Class & Midpoint & $\mathrm{n}_{\mathrm{i}}$ & $\sum \mathrm{n}_{\mathrm{i}}$ & $\mathrm{p}_{\mathrm{i}}$ & $\sum \mathrm{p}_{\mathrm{i}}$ & $\sum \mathrm{n}_{\mathrm{i}}(\%)=\mathrm{X}$ & $\sum \mathrm{p}_{\mathrm{i}}(\%)=\mathrm{Y}$ \\
\hline $0.1-0.9$ & 0.5 & 64 & 64 & 32 & 32 & $64 \%$ & $23 \%$ \\
\hline $1-1.9$ & 1.5 & 20 & 84 & 30 & 62 & $84 \%$ & $44 \%$ \\
\hline $2-2.9$ & 2.5 & 5 & 89 & 12.5 & 74.5 & $89 \%$ & $53 \%$ \\
\hline $3-3.9$ & 3.5 & 4 & 93 & 14 & 88.5 & $93 \%$ & $63 \%$ \\
\hline $4-4.9$ & 4.5 & 4 & 97 & 18 & 106.5 & $97 \%$ & $76 \%$ \\
\hline $9-9.9$ & 9.5 & 2 & 99 & 19 & 125.5 & $99 \%$ & $90 \%$ \\
\hline $14-14.9$ & 14.5 & 1 & 100 & 14.5 & 140 & $100 \%$ & $100 \%$ \\
\hline
\end{tabular}


TABLE 6. CONCENTRATION INDICES AND VARIABILITY, FOR THE PERIODS 1965-2005, 1965-1984 AND 1985-2005, AND FOR DIFFERENT SEASONS.

\begin{tabular}{|c|c|c|c|c|c|c|}
\hline $\begin{array}{l}\text { Meteorologi- } \\
\text { cal stations }\end{array}$ & Periods & Summer & Autumn & Winter & Spring & $\begin{array}{c}\text { Standard de- } \\
\text { viation (\%) }\end{array}$ \\
\hline \multirow{3}{*}{ Arica } & $1965-2005$ & 0.47 & 0.41 & 0.58 & 0.40 & $8 \%$ \\
\hline & $1965-1984$ & 0.39 & $* * *$ & 0.46 & 0.39 & $4 \%$ \\
\hline & $1985-2005$ & 0.49 & 0.41 & 0.63 & ++ & $11 \%$ \\
\hline \multirow{3}{*}{ Iquique } & $1965-2005$ & 0.34 & 0.75 & 0.50 & ++ & $21 \%$ \\
\hline & $1965-1984$ & $* * *$ & ++ & 0.42 & $* * *$ & \\
\hline & 1985-2005 & 0.34 & 0.66 & 0.57 & ++ & $17 \%$ \\
\hline \multirow{3}{*}{ Antofagasta } & 1965-2005 & 0.49 & 0.48 & 0.63 & 0.44 & $8 \%$ \\
\hline & 1965-1984 & 0.50 & 0.36 & 0.63 & 0.44 & $11 \%$ \\
\hline & 1985-2005 & 0.46 & 0.50 & 0.62 & 0.42 & $8 \%$ \\
\hline \multirow{3}{*}{ Copiapó } & 1965-2005 & ++ & 0.65 & 0.64 & 0.61 & $2 \%$ \\
\hline & 1965-1984 & $* * *$ & 0.51 & 0.53 & 0.68 & $9 \%$ \\
\hline & $1985-2005$ & ++ & 0.71 & 0.70 & 0.36 & $20 \%$ \\
\hline \multirow{3}{*}{ La Serena } & $1965-2005$ & 0.53 & 0.79 & 0.69 & 0.79 & $12 \%$ \\
\hline & 1965-1984 & ++ & 0.70 & 0.64 & 0.72 & $4 \%$ \\
\hline & 1985-2005 & 0.53 & 0.80 & 0.73 & 0.75 & $12 \%$ \\
\hline \multirow{3}{*}{ Valparaíso } & $1965-2005$ & 0.72 & 0.68 & 0.61 & 0.65 & $5 \%$ \\
\hline & 1965-1984 & 0.67 & 0.64 & 0.59 & 0.64 & $3 \%$ \\
\hline & 1985-2005 & 0.72 & 0.71 & 0.62 & 0.65 & $5 \%$ \\
\hline \multirow{3}{*}{ Santiago } & $1965-2005$ & 0.65 & 0.64 & 0.62 & 0.65 & $2 \%$ \\
\hline & 1965-1984 & 0.61 & 0.64 & 0.60 & 0.63 & $2 \%$ \\
\hline & 1985-2005 & 0.67 & 0.65 & 0.63 & 0.67 & $2 \%$ \\
\hline \multirow{3}{*}{ Curicó } & $1965-2005$ & 0.57 & 0.62 & 0.58 & 0.59 & $2 \%$ \\
\hline & 1965-1984 & 0.55 & 0.59 & 0.56 & 0.54 & $2 \%$ \\
\hline & 1985-2005 & 0.58 & 0.65 & 0.60 & 0.63 & $3 \%$ \\
\hline \multirow{3}{*}{ Chillán } & $1965-2005$ & 0.60 & 0.60 & 0.57 & 0.57 & $2 \%$ \\
\hline & 1965-1984 & 0.55 & 0.57 & 0.55 & 0.57 & $1 \%$ \\
\hline & 1985-2005 & 0.65 & 0.63 & 0.58 & 0.58 & $4 \%$ \\
\hline \multirow{3}{*}{ Concepción } & 1965-2005 & 0.63 & 0.60 & 0.58 & 0.61 & $2 \%$ \\
\hline & 1965-1984 & 0.60 & 0.58 & 0.58 & 0.59 & $1 \%$ \\
\hline & 1985-2005 & 0.67 & 0.62 & 0.59 & 0.64 & $3 \%$ \\
\hline \multirow{3}{*}{ Temuco } & 1965-2005 & 0.62 & 0.59 & 0.56 & 0.58 & $3 \%$ \\
\hline & 1965-1984 & 0.62 & 0.57 & 0.54 & 0.57 & $3 \%$ \\
\hline & $1985-2005$ & 0.62 & 0.60 & 0.57 & 0.59 & $2 \%$ \\
\hline \multirow{3}{*}{ Valdivia } & 1965-2005 & 0.60 & 0.62 & 0.58 & 0.58 & $2 \%$ \\
\hline & 1965-1984 & 0.58 & 0.59 & 0.56 & 0.57 & $2 \%$ \\
\hline & $1985-2005$ & 0.62 & 0.65 & 0.60 & 0.60 & $2 \%$ \\
\hline
\end{tabular}




\begin{tabular}{|c|c|c|c|c|c|c|}
\hline $\begin{array}{l}\text { Meteorologi- } \\
\text { cal stations }\end{array}$ & Periods & Summer & Autumn & Winter & Spring & $\begin{array}{c}\text { Standard de- } \\
\text { viation (\%) }\end{array}$ \\
\hline \multirow{3}{*}{ Osorno } & $1965-2005$ & 0.59 & 0.59 & 0.56 & 0.55 & $2 \%$ \\
\hline & $1965-1984$ & 0.58 & 0.58 & 0.55 & 0.55 & $2 \%$ \\
\hline & $1985-2005$ & 0.61 & 0.61 & 0.57 & 0.56 & $3 \%$ \\
\hline \multirow{3}{*}{ Puerto Montt } & $1965-2005$ & 0.57 & 0.57 & 0.54 & 0.54 & $2 \%$ \\
\hline & $1965-1984$ & 0.55 & 0.56 & 0.52 & 0.53 & $2 \%$ \\
\hline & $1985-2005$ & 0.59 & 0.57 & 0.55 & 0.56 & $2 \%$ \\
\hline \multirow{3}{*}{ Coyhaique } & $1965-2005$ & 0.61 & 0.61 & 0.61 & 0.60 & $0 \%$ \\
\hline & $1965-1984$ & 0.60 & 0.61 & 0.61 & 0.60 & $1 \%$ \\
\hline & $1985-2005$ & 0.62 & 0.61 & 0.61 & 0.61 & $1 \%$ \\
\hline \multirow{3}{*}{ Balmaceda } & $1965-2005$ & 0.60 & 0.60 & 0.60 & 0.59 & $1 \%$ \\
\hline & $1965-1984$ & 0.60 & 0.60 & 0.60 & 0.57 & $2 \%$ \\
\hline & $1985-2005$ & 0.61 & 0.60 & 0.61 & 0.61 & $1 \%$ \\
\hline \multirow{3}{*}{$\begin{array}{l}\text { Punta Are- } \\
\text { nas }\end{array}$} & $1965-2005$ & 0.60 & 0.59 & 0.57 & 0.59 & $1 \%$ \\
\hline & $1965-1984$ & 0.59 & 0.59 & 0.57 & 0.59 & $1 \%$ \\
\hline & $1985-2005$ & 0.60 & 0.60 & 0.56 & 0.58 & $2 \%$ \\
\hline
\end{tabular}

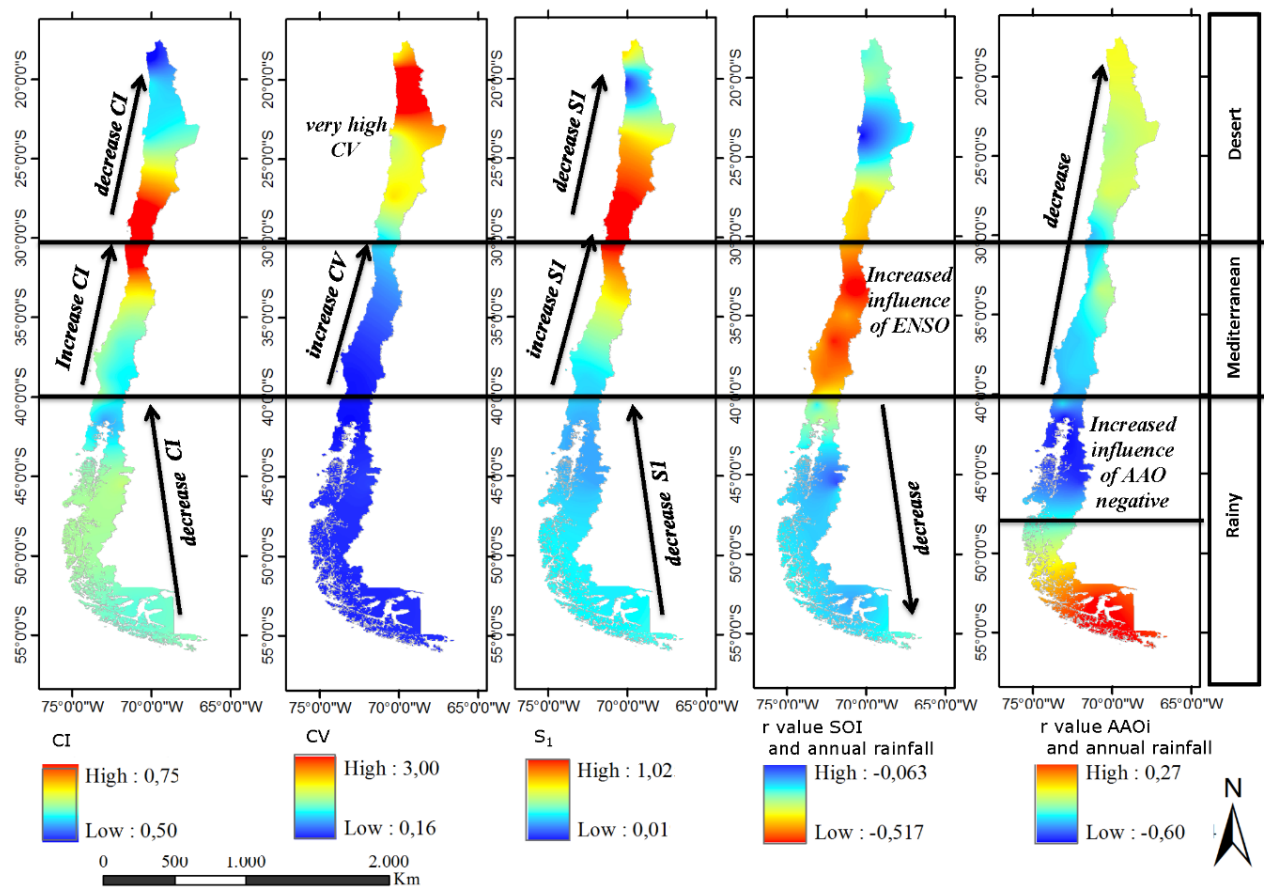

Fig. 4. Regionalization climate of Chile from CI, CV, S1, SOI and AAO. 


\section{DISCUSSION AND CONCLUSIONS}

Concentration of daily rainfall obtained through the CI confirmed that south and central Chile have similar values as those of the Iberian Peninsula, high values of CI for Mediterranean climates and moderate and low CI values for rainy oceanic climates. However, for desert climates, there are higher gradients of CI than those observed in Iran and China. In Chile there is a greater concentration of precipitation with values of CI above 0,70. In Chile, the value of CI in northern coastal regions, where it rains less than $5 \mathrm{~mm}$ per year, are very low ( $\leq$ 0.57 ). The reason of those values can be find in the fact that the first group ( 0.1 to $0.9 \mathrm{~mm}$ ) holds more than $50 \%$ of the rainy days, accumulating more than $20 \%$ of the total rainfall. This weakens the curve of concentration approximating it to a straight line of equal distribution (Fig. 2), which gives a very low value of the CI.

There is a very significant and positive correlation between the values of $\mathrm{CI}$ and $\mathrm{CV}$, as well as between the values of $\mathrm{CI}$ and S1 from La Serena towards the south. This expresses the agreement of these indices with the spatial distribution of Mediterranean and ocean climates. From a statistical point of view, it is necessary to find a different kind of analysis for desert climates, due to the extremely abnormal conditions.

The 1985-2005 sub-period is characterized by higher rainfall concentration, which could be the result of more El Niño phenomena. This questions the second hypothesis, since it was initially proposed that a rainfall increase would reduce daily concentrations. The overall increase of annual and seasonal value of CI, moving from the first to the second sub-period, could be related to climate change. If confirmed in coming decades, it would imply a worse time distribution, more concentrated and torrential rainfall, with all the negative effects that this entails.

\section{ACKNOWLEDGEMENTS}

Thank to those who financed this research, Fondecyt (National Fund for Scientific and Technological Development) Initiation Project $N^{\circ} 11130629$ and U-APOYA program at the University of Chile (CSSOC-2012-292). Also to Pamela Figueroa for helping with the translation.

\section{REFERENCES}

ALIJANI, B., J. O'BRIAN \& B. YARNAL, 2008. Spatial analysis of precipitation intensity and concentration in Iran. Theoretical and Applied Climatology, 94: 107-124.

BENHAMROUCHE, A. \& J. MARTÍNVIDE, 2012. Avances metodológicos en el análisis de la concentración diaria de la precipitación en la España peninsular. Anales de Geografía de la Universidad Complutense, 32 (1): 11-27.

GARREAUD, R., 2007. Precipitation and circulation covariability in the extratropics. Journal of Climate, 20: 4789-4797.

LI, X., F. JIANG, L. LI \& G. WANG, 2011. Spatial and temporal variability of precipitation concentration index, concentration degree and concentration period in Xinjiang, China. International Journal of Climatology, 31: 1679-1693.

MARTÍN-VIDE, J., 1984. Análisis de la irregularidad de la precipitación diaria en el litoral mediterráneo de la Península Ibérica. Revista de Geofísica, 40 (1): 101-106.

MARTÍN-VIDE, J., M. PROHOM, M. BOHIGAS, J. PEÑA, P. ESTEBAN \& D. MONTSERRAT, 2001. Índices de irregularidad temporal y dimensión fractal de la precipitación anual en España. en: El Tiempo del Clima. Pérez-Cueva, López Baeza, Tamayo (eds.), Buñol, AEC y Garmas Impresores: 157-166. 
MARTÍN-VIDE, J., 2003. El tiempo y el clima. Colección Cuadernos de Medio Ambiente. Rubes Editorial. Barcelona, España.

MARTÍN-VIDE， J., 2004. Spatial distribution of a daily precipitation concentration index in peninsular Spain. International Journal of Climatology, 24: 959-971.

QUINTANA, J. \& P. ACEITUNO, 2006. Trends and interdecadal variability of rainfall in Chile. In: Proceedings of 8 ICSHMO, INPE, Brazil, Foz do Iguaçu: 371-372.

QUINTANA, J. \& P. ACEITUNO, 2012. Changes in the rainfall regime along the extratropical west coast of South America (Chile): 30-43 S. Atmósfera, 25 (1):1-22.
SÁNCHEZ-LORENZO, A. \& J. MARTÍNVIDE, 2006. Distribución espacial de la concentración pluviométrica diaria en la Península Ibérica. In: Proceedings $5^{a}$ Asamblea Hispano Portuguesa de Geodesia y Geofisica, sesión Climatología y Cambio Climático (CDROM).

SILVESTRI, G. \& C. VERA, 2003. Antarctic Oscillation signal on precipitation anomalies over southeastern South America. Geophysical Research Letters, 30 (21): 21-15.

THOMPSON D. \& J. WALLACE, 2000. Annular modes in the extratropical circulation. Part I: month-to-month variability. Journal of Climate, 13: 1000-1016.

ZHANG, Q., C. XU, M. GEMMER, Y.Q. CHEN \& C. LIU, 2009. Changing properties of precipitation concentration in the Pearl River basin, China. Stochastic Environmental Research and Risk Assessment, 23: 377-385.

\section{Imagen de Investigaciones GEOGRáFICAS}

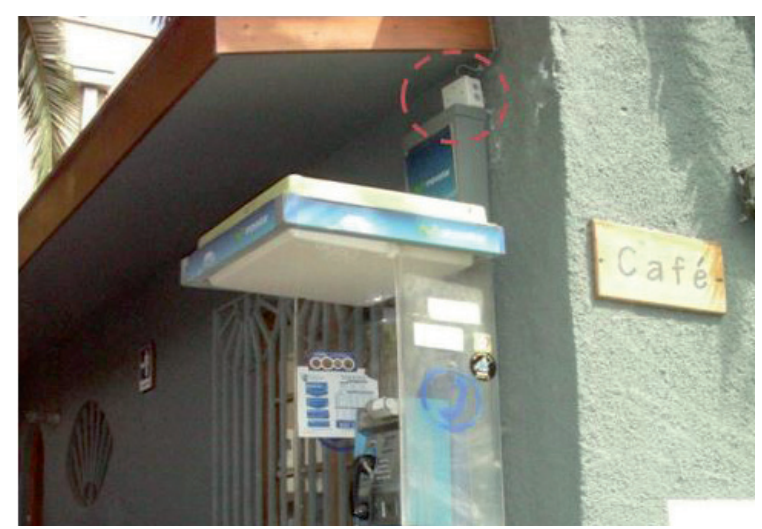

Sensor Logtag instalado en el Museo La Sebastiana, Cerro Bellavista. Este sensor fue instalado por el Laboratorio de Medioambiente y Territorio el año 2008, en el marco del proyecto Fondecyt 1080080 "Sustentabilidad ambiental urbana, justicia socioambiental y escenarios de calidad de vida futura en la metrópolis de Santiago - Valparaíso y en la ciudad intermedia de Chillán", y a partir de ese año registra la temperatura atmosférica en intervalos de tiempo de 1 hora. El sensor se encuentra al interior de la caja blanca señalada con un círculo rojo en la fotografía, considerando las recomendaciones metodológicas de la literatura de clima urbano. Aún se mantienen los registros de temperatura en este punto. El sensor ha sido reemplazado en enero de 2014 por uno de marza Hobo previamente calibrado, que posee una mayor vida útil, con aportes del Proyecto Fondecyt 1130305 "Estudio y modelación del clima urbano a escala local, como base para la proposición de lineamientos de adaptación frente al cambio climático en una red de ciudades Chilenas". pamelasmit@gmail.com

Fuente: Laboratorio de Medioambiente y Territorio, Universidad de Chile. 